\title{
CLINICAL AND IMMUNOLOGIC ASSESSMENT OF A COMPLEX OF THERAPEUTIC-PREVENTIVE MEASURES CONCERNING CHRONIC CATARRHAL GINGIVITIS IN CHILDREN WITH COMORBID DIABETES MELLITUS
}

DOI: 10.36740/WLek202002117

\author{
Oksana I. Godovanets ${ }^{1}$, Anastasiia V. Kotelban' ${ }^{1}$, Petro V. Moroz ${ }^{2}$, Oleksandr O. Vitkovskyi ${ }^{1}$, Tetiana S. Kitsak', \\ Nazar M. Navolskyi ${ }^{1}$ \\ 'DEPARTMENT OF PEDIATRIC STOMATOLOGY, HIGHER STATE EDUCATIONAL ESTABLISHMENT OF UKRAINE «BUKOVINIAN STATE MEDICAL UNIVERSITY», \\ CHERNIVTSI, UKRAINE \\ 2DEPARTMENT OF SURGERY №1, HIGHER STATE EDUCATIONAL ESTABLISHMENT OF UKRAINE «BUKOVINIAN STATE MEDICAL UNIVERSITY», \\ CHERNIVTSI, UKRAINE
}

\begin{abstract}
The aim of our study is to increase the efficacy of treatment of chronic catarrhal gingivitis in children suffering from type 1 diabetes mellitus by means of improvement of the methods of pharmacological correction on the basis of investigation of clinical-immunologic peculiarities of the disease.

Materials and methods: 2 groups of the study were formed. Children received basic insulin therapy. The treatment of chronic catarrhal gingivitis in children from the main group were suggested the antiseptic solution "Decasan"; pill of a probiotic action "BioGaia ProDentis" and the immune modulator "Imupret". Children from the comparative group were treated according to the common scheme.

Results: The state of the oral hygiene in all the children after treatment improved considerably. According to PMA index inflammatory process was completely eliminated in children from the main group. A similar tendency was observed concerning sextants with gingival bleeding. In children dental calculus was lacking after treatment. Lysozyme activity in the oral fluid of children after treatment increased approximately $37.50 \%$ in the main group, and $16,67 \%$ - in the comparison group. A similar tendency was found concerning slgA level.
\end{abstract}

Conclusions: Therefore, conducted course of the treatment concerning chronic catarrhal gingivitis promoted considerable improvement of the periodontal tissue in children.

KEY WORDS: type 1 diabetes mellitus, gingivitis, immunoglobulins, lysozyme, antiseptic, probiotic, immune modulator

\section{INTRODUCTION}

According to the views of certain authors chronic catarrhal gingivitis (CCG) should be considered as the first stage in the development of generalized periodontitis, since even at the early stages of gingivitis changes of the whole periodontal complex are found. In case of somatically complicated conditions both forms of pathology are associated between themselves in one chain of events: generalized gingivitis with a great degree of probability is transmitted into generalized periodontitis, and inflammation in the gums remains, as well as the degree of manifestation and involvement of other periodontal components increase. In this respect an important task of a pediatric dentist is timely detection and adequate treatment of gingivitis in order to prevent development of more severe forms of periodontal tissue lesions. The issues associated with comorbid somatic diseases available are especially topical, since they deteriorate periodontal tissue state.

At the modern stage of development of stomatology gingivitis is treated by antiseptic agents of a wide spectrum of action, enzymes, fungicides, anti-protozoan drugs, anti- biotics [1-5], probiotics [6-8], and immune modulators in case of reduced local immunity [9-11]. Different schemes of treatment of this pathology against the ground of diabetes mellitus (DM) are presented in literature [12-15].

We suggest a comprehensive treatment of CCG in children including insulin therapy according to basic-bolus scheme, topical administration of antiseptic solution possessing a pronounced bactericidal action concerning gram-positive, gram-negative and anaerobic microflora, as well as fungicidal effect, probiotic drug of an immunotropic action on the basis of $L$. reuteri, an oral immune modulator of a plant origin, which action is directed to stimulation of non-specific reaction of the immune system at the expense of increased phagocytosis of macrophages and granulocytes, and intracellular destruction of bacteria in the process of phagocytosis.

\section{THE AIM}

Objective of our study is to increase the efficacy of treatment of chronic catarrhal gingivitis in children suffering from type 
1 diabetes mellitus by means of improvement of the methods of pharmacological correction on the basis of investigation of clinical-immunologic peculiarities of the disease.

\section{MATERIALS AND METHODS}

With the purpose to assess improved method of treatment and prevention of CCG in children with type $1 \mathrm{DM}$ under clinical conditions 54 children aged 12 years afflicted with CCG and comorbid type 1 DM ( 32 boys and 22 girls) were examined. They were divided into two groups: the main one (30 individuals) and the group of comparison (24 individuals).

Operiodontal status was evaluated by detection of Stelrad hygiene index and periodontal indices (papillary-marginal index (PMA), Svrakov's iodine number, community periodontal index (CPI). The state of local humoral immunity was assessed by the levels of sIgA and lysozyme in the oral fluid by means of simple radial diffusion method in agar according to G. Manchini, using mono-specific standard antisera against the examined classes of immunoglobulins («Microgen», Russia) and lysozyme according to G. Gorin’s method modified by A.P. Levytskyi and O.O. Zhygina.

The degree of probability of the obtained results in case of normal distribution of both samples was statistically processed according to Student-Fisher's criterion, in other cases - U-Wilcoxon for independent sampling and
T-Wilcoxon for dependent sampling, Pearson correlation analysis for normally distributed sampling, and in other cases - Spearman analysis.

Treatment of CCG in children with comorbid DM against insulin therapy and basic-bolus scheme included teaching hygienic individual care of the oral cavity, professional hygiene and oral cavity sanation. The children from the main group were suggested to rinse the oral cavity with the antiseptic solution "Decasan" $0,02 \%$ topically (in dilution with boiled water 1:2 ratio) twice a day during 5-7 days; chewing 1 pill of a probiotic action "BioGaia ProDentis" twice a day during 2 weeks, and since the beginning of the second week of treatment - oral administration of the immune modulator "Imupret", 25 drops 3 times a day during 3 weeks. Chronic catarrhal gingivitis of children from the comparative group was treated according to the common scheme: rinsing with antiseptic solution «Chlorhexidine bigluconate» $0,05 \%$ twice a day till the clinical effect of elimination of inflammatory signs, and «Rotocan» solution twice a day during 5-7 days; oral administration of the immune modulator «Echinacea» 5 drops (in dilution with boiled water 1:2 ratio) 3 times a day 30 minutes before meals during 3 weeks.

\section{RESULTS AND DISCUSSION}

Analysis of children complains suffering from CCG and $\mathrm{DM}$ at the moment of examination showed that over

Table 1. Changes of periodontal tissue state and oral cavity hygiene in children suffering from chronic catarrhal gingivitis with comorbid diabetes mellitus using different methods of treatment, $(\mathrm{M} \pm \mathrm{m})$

\begin{tabular}{|c|c|c|c|c|}
\hline Index & Subgroups & Before treatment & After treatment & $\mathbf{P}$ \\
\hline \multirow{2}{*}{$\begin{array}{l}\text { Stelrad index, } \\
\text { points }\end{array}$} & main $(n=30)$ & $1,63 \pm 0,11$ & $0,45 \pm 0,03$ & $\mathrm{p}<0,05$ \\
\hline & comparison $(n=24)$ & $1,67 \pm 0,10$ & $0,69 \pm 0,04^{*}$ & $\mathrm{p}<0,05$ \\
\hline \multirow{2}{*}{ PMA index, \% } & main $(n=30)$ & $44,29 \pm 3,09$ & 0 & $p<0,01$ \\
\hline & comparison $(n=24)$ & $44,13 \pm 3,17$ & $11,29 \pm 2,57^{*}$ & $\mathrm{p}<0,01$ \\
\hline \multirow{2}{*}{$\begin{array}{l}\text { Svrakov's number, } \\
\text { points }\end{array}$} & main $(n=30)$ & $3,47 \pm 0,19$ & $0,31 \pm 0,10$ & $\mathrm{p}<0,05$ \\
\hline & comparison $(n=24)$ & $3,22 \pm 0,31$ & $0,85 \pm 0,05^{*}$ & $\mathrm{p}<0,05$ \\
\hline \multirow{2}{*}{ Bleeding, sextants } & main $(n=30)$ & $4,42 \pm 0,28$ & 0 & $\mathrm{p}<0,01$ \\
\hline & comparison $(n=24)$ & $4,71 \pm 0,29$ & $0,92 \pm 0,20^{*}$ & $p<0,01$ \\
\hline \multirow{2}{*}{ Dental calculi, sextants } & main $(n=30)$ & $1,69 \pm 0,29$ & 0 & $\mathrm{p}<0,05$ \\
\hline & comparison $(n=24)$ & $2,04 \pm 0,34$ & 0 & $p<0,05$ \\
\hline
\end{tabular}

Notes. 1. $p$ - difference between the indices in the groups of observation before and after treatment is reliable $(p<0,05) ; 2 .{ }^{*}-$ difference between the indices of the main and comparative groups in the dynamics of treatment is reliable $(\mathrm{p} 1<0,05)$.

Table 2. Changes of humoral immunity indices in the oral fluid of children suffering from chronic catarrhal gingivitis with comorbid diabetes mellitus using different methods of treatment, $(M \pm m)$

\begin{tabular}{|c|c|c|c|c|}
\hline \multirow{2}{*}{ Index } & \multicolumn{2}{|c|}{ Before treatment } & \multicolumn{2}{|c|}{ After treatment } \\
\hline & Main subgroup $(n=30)$ & Comparison subgroup $(n=24)$ & Main subgroup $(n=30)$ & Comparison subgroup $(n=24)$ \\
\hline Lysozyme, g/L & $0,05 \pm 0,001$ & $0,05 \pm 0,001$ & $0,08 \pm 0,001^{*}$ & $0,06 \pm 0,002^{\circ}$ \\
\hline $\operatorname{slg} A, g / L$ & $0,23 \pm 0,001$ & $0,25 \pm 0,001$ & $0,35 \pm 0,001^{*}$ & $0,28 \pm 0,001^{\circ, *}$ \\
\hline
\end{tabular}

Notes. $1^{*} p$ - difference between the indices in the groups of observation before and after treatment is reliable $(p<0,05) \cdot 2 .^{\circ}-$ difference between the indices of the main and comparative groups is reliable $(\mathrm{p} 1<0,05)$. 
$76,47 \%$ children from the main group and 78,07 \% children from the group of comparison complain of gingival bleeding. $58,53 \%$ children from the main group complain of burning sensations, itching and pain in the gums. In the group of comparison all these signs are mentioned by more than $10,43 \%$ children. One fourth of children from both groups of observation did not present any periodontal complains.

Before initiation of treatment of CCG periodontal indices were approximately similar (Table 1 ).

Moderate CCG was a prevailing form among the children from the groups of observation. The mean value of PMA index was $(44,29 \pm 3,09) \%$ in children from the main subgroup and $(44,13 \pm 3,17) \%$ in children from the subgroup of comparison. Children from the groups of observation were characterized by a high amount of sextants with bleeding: $(4,42 \pm 0,28)$ - in children from the main subgroup and $(4,71 \pm 0,29)$ - in children from the subgroup of comparison. The mean value of sextant affliction by dental calculus was the following: $(1,69 \pm 0,29)$ and $(2,04 \pm 0,34)$ respectively. The results of questionnaire concerning their keeping to oral hygiene are indicative of insufficient attention of children to cleaning teeth. Stelrad index parameters indicate unsatisfactory oral hygiene among children from the groups of observation: in the main subgroup - $(1,63 \pm 0,11)$ and $(1,67 \pm 0,10)$ - in the subgroup of comparison.

Clinical examination of children from the main subgroup immediately after conducted treatment (the $21^{\text {st }}$ day) showed that inflammatory process was completely eliminated in all the children. In the subgroup of comparison inflammatory process disappeared in 11 children $(45,83 \%)$ and in 13 children $(54,17 \%)$ the state of the periodontal tissue improved. After treatment the mean value of PMA index in children from the subgroup of comparison was $11,29 \%$.

Oral hygiene in all the children improved considerably: Stelrad index mean value in children from the main subgroup immediately after the conducted treatment was $(0,45 \pm 0,03)$ which is $34,78 \%$ lower than those indices from the subgroup of comparison $\left(\mathrm{p}_{1}<0,05\right)$. The results obtained are indicative of satisfactory oral hygiene and elimination of one of the main periodontal-pathogenic factors.

Svrakov's iodine number after the conducted treatment was indicative of decreased inflammatory process in the periodontal tissue of children from the main subgroup 11,19 times as much $(\mathrm{p}<0,05)$ and 3,79 times - in children from the subgroup of comparison $(\mathrm{p}<0,05)$. To our opinion, available latent residual inflammatory process is associated with glucose-mediated lesion of the vascular wall in the periodontal tissue under conditions of DM.

Estimating the periodontal tissue state by CPI index it should be noted that after the conducted treatment sextants with gingival bleeding were absent in $100,00 \%$ of children from the main subgroup, while in children from the group of comparison - only in 11 of the examined children $(45,83 \%)$. In both groups sextants and dental calculi disappeared as well.

Detection of topical humoral immunity indices is important for a comprehensive assessment of the periodontal tissue state in children from both groups. Lysozyme concentration after treatment increased $37,50 \%$ in children from the main subgroup and $16,66 \%$ - in the subgroup of comparison $(\mathrm{p} 1<0,05)$. These results are indicative of stabilization of neutrophil cellular membrane disorders which considerably decreases "immune" inflammation (Table 2).

Estimating sIgA level it should be noted that after the conducted therapeutic-preventive measures in children from the main subgroup its content increased $34,29 \%$ and it was $-(0,35 \pm 0,001) \mathrm{g} / \mathrm{L},(\mathrm{p}<0,05)$, and in children from the subgroup of comparison - only $10,71 \%(\mathrm{p}<0,05)$, and difference between them was $20,00 \%\left(p_{1}<0,05\right)$. These results are indicative of an increased reactivity of the children's organisms under CCG conditions against the ground of DM.

\section{CONCLUSIONS}

Therefore, the obtained results of clinical-laboratory examinations are indicative of an improved periodontal status and topical humoral mechanisms of immune protection in the oral cavity of children suffering from CCG against the ground of DM, when antiseptic, probiotic and immune modulators are used in a comprehensive treatment. These data confirm greater efficacy of the suggested therapeutic-preventive complex in comparison with the common scheme of treatment.

\section{REFERENCES}

1. Antonenko Mlu, Sydelnykova LF, Dudnykova M0. The effectiveness of the inclusion of etiotropic drugs in the complex oral hygiene in the early stages of periodontal disease. Sovrem. stomatoloh. 2010;1:49-52.

2. Kovalchuk VP, Kondratiuk VM. New antiseptic agents of military virobnitstva. The characteristics of anti-microbial activities are porous. Mystetstvo likuvannia. 2009;26:4-8.

3. Mazur YP, Bakshutova NA, Stavskaia DM. Clinical and microbiological efficacy of using local antimicrobial and antiseptic drugs in the treatment of periodontal diseases. Sovremennaia stomatolohyia. 2014;1:32-8.

4. Yudyna NA, Kurochkyna Alu. Control of biofilm in modern strategies for the prevention and treatment of dental diseases. Stomatolohyia. 2009;3:77-81.

5. Yushchuk ND, Balmasova YP, Tsarev VN. Antibiotics and anti-infective immunity. M.: Praktycheskaia medytsyna; 2013. $232 \mathrm{~s}$.

6. Hodovanets $\mathrm{Ol}, \mathrm{Moroz}$ AV, Popesku DH. Application of probiotics in dentistry. Klinichna ta eksperymentalna patolohiia. 2016;2(56):206-9.

7. Levytskyi AP, Nykolyshyn AK, Stupak EP, Skydan KV. Dysbiotic aspects of the pathogenesis, prevention and treatment of dental diseases. Problemy ekolohii ta medytsyny. 2011;3-4:103.

8. Bonifait L, Chandad F, Grenier D. Probiotics for oral health: Myth or Reality. JCDA. 2009;75(8):585-90.

9. Makarevych VA. The efficacy of imupret in immunorehabilitation of patients with herpetic stomatitis. Fitoterapiia. 2013;1:28-31.

10. Yuriev KL. From separate to general, or relay is taken by Imupret.Ukr. med. chasopys. 2008;3(65):65-8.

11. Braathen G, Ingildsen V, Twetman S. Presence of Lactobacillus reuteri in saliva coincide with higher salivary IgA in young adults after intake of probiotic lozenges. Beneficial microbes. 2017;8(1):17-22. 
12. Alshehri FA, Javed F. Impact of scaling and root planing on clinical periodontal status and glycemic levels in prediabetic patients. Interventional medicine and applied science. 2015;7(1):17-21.

13. Hanes PJ, Krishna R. Characteristics of inflammation common to both diabetes and periodontitis: are predictive diagnosis and targeted preventive measures possible? The EPMA journal. 2010;1(1):101-16.

14. Katagiri S, Nagasawa T, Kobayashi H, Takamatsu H, Bharti P, Izumiyama $\mathrm{H}$. Improvement of glycemic control after periodontal treatment by resolving gingival inflammation in type 2 diabetic patients with periodontal disease. J. Diabetes Invest. 2012;3(4):402-9.

\section{ORCID and contributionship:}

Oksana I.Godovanets - 0000-0002-1889-3893 ${ }^{A, F}$

Anastasiia V. Kotelban - 0000-0001-8266-3454

Petro V. Moroz - 0000-0002-7131-8863 ${ }^{B, E}$

Oleksandr O. Vitkovskyi - 0000-0001-7583-2619

Tetiana S. Kitsak - 0000-0003-1253-8919E

Nazar M. Navolskyi 0000-0002-4451-1801 ${ }^{E}$

\section{Conflicts of interest:}

Authors declare no conflict of interest.

\section{CORRESPONDING AUTHOR}

Anastasiia V. Kotelban

Department of Pediatric Stomatology,

Higher State Educational Establishment of Ukraine

«Bukovinian State Medical University»

Teatralna sq., 2, 58001, Chernivtsi, Ukraine

tel: +380500794102

e-mail: anastasiia.kotelban@gmail.com

Received: 08.05.2019

Accepted: 04.12.2019

A - Work concept and design, B - Data collection and analysis, C - Responsibility for statistical analysis, D - Writing the article, $\mathbf{E}$-Critical review, $\mathbf{F}$ - Final approval of the article 